\title{
The Floating Market of Lok Baitan, South Kalimantan
}

\author{
Ellyn Normaleni ${ }^{*}$ \\ Faculty of Teaching and Education Science, Lambung Mangkurat University, Banjarmasin, Indonesia \\ Indonesia
}

\begin{abstract}
Tourism plays an important role in the development of local economic. Tourism has been reported contributes significantly in the local development. Floating market in South Kalimantan has potentiality as tourism attraction, but there are limited study of the value of floating market as tourism attraction. This paper aims to describe the floating market in Lok Baitan, South Kalimantan as a potential attraction for local tourism development. This paper confirm that principally floating market is the integral part of the local people in South Kalimantan, especially who live along Barito rivers. Floating market rich in term of natural and cultural resources that is potential to further development as tourism attractions. There are also numerous possibility to develop tourism programs, ranging from nature based tourism to cultural tourism. In the perspective of tourism development, the community based tourism see to be the significant strategy to develop. Through community based tourism, floating market tourism in Lok Baitan will contribute to the local economi development. From such resources, there are numerous possibility for the development of tourism program and attractions. In such a case, floating market tourism in Lok Baitan should be set up following community based tourism. This will become the key for tourism as a component and strategy for local economic development.
\end{abstract}

Keywords: community based tourism development, culture preservation, floating market, South Kalimantan.

\section{INTRODUCTION}

Tourism is one of the important sectors for local economic development. Throughout the world tourism has been promoted as one of the important instrument to initiate and support local development. The benefits of tourism have been widely reported. In countries where culture and nature abundance, tourism especially has potentiality to be developed to support local development. Tourism also provides significant position to promote area becomes widely known. Tourism is geographically important to promote remote and less known area. Tourism not only flourish and developed in well known area, but it is also occurs in remotes area. Therefore, tourism sector is crucial key for the development area $[1,2]$.

Kalimantan Island is important habitat for tropical biodiversity in the worlds. Kalimantan has been reported as home of numerous tribal communities with its own culture. Recently however, the high value of biodiversity in Kalimantan has been under serious degradation due to anthropogenic factor. Illegal logging, forest fire, environmental degradation, rivers pollution area the important aspect contributes to Kalimantan's biodiversity degradation. Mining occurs in every where and contributes to

\footnotetext{
${ }^{*}$ Correspondence address:

Ellyn Normaleni

Address : Lambung Mangkurat University, Brigjen H. Hasan Basri, Banjarmasin 70123
}

numerous wildlifes habitat degradation. Naturally, Kalimantan island is home of numerous potential tourism attraction. In such a case, effort to promote Kalimantan's mega biodiversity as a tourism attraction has been initiated in several regions. Many animals and plants has been identified endemic to Kalimantan, and therefore becomes important object for tourism [3]. Local people in Kalimantan are practicing indigenous knowledge to manage natural resources and results numerous unique landscape [4]. In such a case, the potential of cultural landscape is one of the potential aspects in the development of tourism [5].

One of the important tourism attractions which are found only in Kalimantan is floating market. Floating market is originally in the traditional trading system of people around Barito Rivers. The culture which is related to rivers lead market in the rivers is common and accessible for people. These have been occurring for a long time in South Kalimantan. Floating market is become tradition among Banjarese, a local people along Barito River. In Kalimntan Island, among five provinces in Kalimantan, floating market only found in South Kalimantan. The floating market at Lok Baitan North Kalimantan has long history as a part of the Banjerese life along Barito Rivers [6].

Women are the main participant in floating market systems. Women dominated traders in the floating market rivers. They come from 
numerous villages along Barito Rivers to sell numerous agricultural products, such as vegetables, fruits and spices. Banjarese sellers in floating market using single small traditional boat called Jukung. Activity usually started in early morning. Modern facility was absence and all market activity was supported by traditional equipment. Previous study point out several difference aspect of floating market compared to the modern market in South Kalimantan [6]. Physically, there are no physical buildings in floating market, but in traditional market there are physical buildings to facilitate trading activity. The traditional market is dirty and there are few opportunities to be developed as tourism attraction, but floating marker has its unique aspect which area able to be developed as tourism attraction. In traditional market, market open in the morning to noon, but floating market opens at the morning.

Lok Baitan floating market located at Lok Baitan Village in Sungai Tabuk Sub-district in Banjarese Regency, South Kalimantan. The market has been knows as one of the Banjerese cultur in human-economic activity. The aim of the paper is describes the floating market of Lok Baitan, South Kaliman and its potentiality as tourism attractions. Focus of discussion was to describe the natural and cultural aspect of floating market at Lok Baitan.

\section{RESOURCES OF LOK BAITAN FLOATING MARKET Natural resources}

River is the important aspect among Banjarese along Barito River. Rivers is one of the landscapes's component which are important in human movement. In the absence of road, rivers is the important media for local people transportation [7]. History of intensive uses of rivers in Kalimantan related to the past poor provincial development. The modern era of South Kalimantan comes after the independency of Indonesia from Dutch colonization era. Compared to the Java Island, the development of infrastructure in Kalimantan Island in the first era of Indonesia as new freedon countries was poor. The initial development of public infrastructure in Kalimantan has been started at the fifteen century, where South Kalimantan still under monarchy system. In the early establishment of Indonesia, south Kalimantan declared as part of the Indonesia. The initial development has been initiate in the early of independent era, but because human resources and funding for development was limited, infrastructure deve- lopment was less implemented. In such situation, rivers plays an important role for local people movement.

In the modern era of South Kalimantan, the uses of rives has been widely recognized important. Rives still plays an important roles in numerous industrial activity in South Kalimantan. The recent development program of road and infrastructure in Kalimantan cannot replace the position of rivers as a media for human movement. It is particularly import in the remotes area in south Kalimantan, where infrastructure is impossible to build. South Kalimantan has abundance rivers ecosystems which are important in people daily life. Rivers has become the integral part of local people in Kalimantan and therefore it is important to separate rives and people in the recent modern development era in South Kalimantan. It is especially can be observed in floating market (Fig.1), where traditional market in barito Rivers occurs in the modern era [8].

Numerous commodities was sold in floating market, most of them are local fruit and vegetables (Fig. 2). It is representing the diversity of fruit and vegetables from agricultural land and home gardens of remotes area in South Kalimantan. Natural attractions that can be enjoyed around the village are encompasses the view of the village along the river, the view of the village along the village road and small rivers that divided the village. These natural resources need to be conserved integrally, especially to ensure the sustainability of natural resources [9].

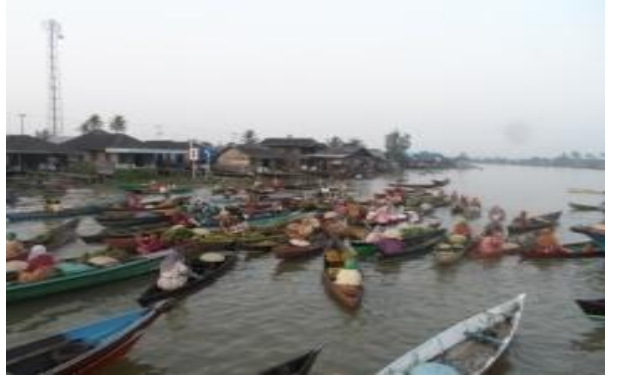

Figure 1. The activity of floating market in Lok Baitan, South Kalimantan

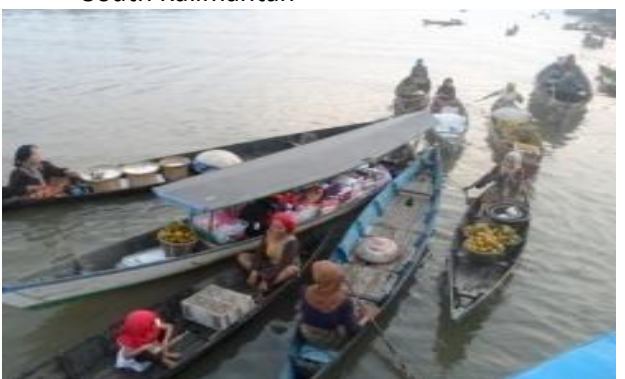

Figure 2. Numerous commodity was sold in Lok baitan floating market 


\section{Cultural Resources}

Culture is an important part of human life. In Indonesia, it is estimated about 300 tribal community life throughout archipelago, from Sabang in the West to Merauke in the east. The diversity of local culture in Indonesia is a potential resources for tourism development.

Social interaction, visiting the neighbors by rowing through the river from one house to another house, cooking together, participating and enjoyingng traditional cultural activity are the among potential cultural attraction for culture-based tourism development. According to scholar, culture is the important capitals for tourism destination [10]. Banjarese daily life system and culture are also potential to develop as tourism potential attractions.

Culinary richness is one of the representative of cultural richness, especially in managing resources and preparing foods. Banjarese rich in term of culinary due to the support of diversity of spices, herbs, vegetate and fruit. Many of them are endemic. Local people in South Kalimantan has ability to recognize and prepare numerous material to becomes specific menu which are differs to the other menu in Indonesia. This cultural richness is one of the important aspect for future culture-based tourism in South Kalimantan, including culinary tourism inside the programs [11].

\section{PROGRAMS ATTRACTIONS}

Tourism program and activity is the crucial component of tourism. In such a case, therefore, inventorying and assessing tourism attraction was considered important. In Lok Baitan floating market, basically tourism attraction can be classified into natural and cultural tourism potential attraction. These can be important resources for tourism development [12].
The activity on Lok Baintan floating market starts around 5 am in the morning until $12 \mathrm{pm}$ in the afternoon. The number of traders in the floating market is uncertain, it depends on the available commodities that they want to be sold. Mostly the commodities are sold come from their own plantation crops. Numerous tourism programs and activity can be developed. Tourists can enjoy the scenery of natural big river, the settlements alongside the river that describes the life of the local people with the river culture. Besides watching trading activity between the traders and the customers, tourists can also enjoy the sensation of eating on the jukung or kelotok and the tourists are also allowed to row the jukung themselves like the traders do (Table 1).

Banjarese is rich in term of culinary which are a potential to be developed in culinary tourism. Banjarese traditional food is including lontong banjar, nasi kuning, mie habang, soto banjar, nasi sop and masak habang. Banjarese traditional cakes are babongko, gaguduh, apam, and kokoleh (Fig. 3). Local fruit can only be found and enjoyed only on its harvesting time. These can be managed to enrich floating market tourism in South Kalimantan [11].

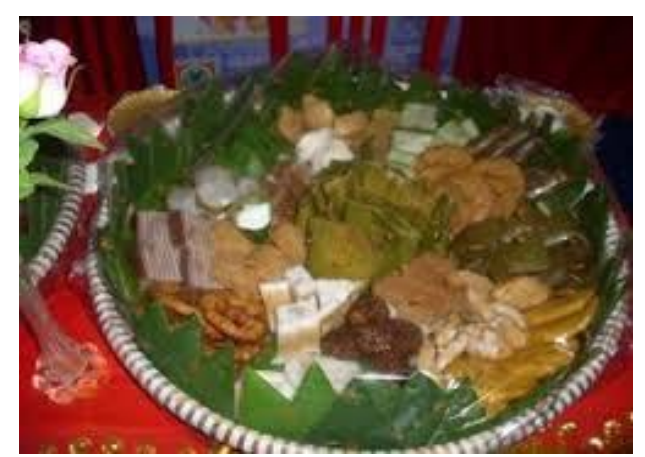

Figure 3. Diversity of traditional cake sold in Lok Baitan Floating market

Table 1. The spectrum of tourism in Lok Baitan area and the potential activity to be developed and integrated in floating market development

\begin{tabular}{llll}
\hline \multicolumn{2}{l}{ Tourism Category } & & Activity \\
$\checkmark \checkmark$ & Nature-based tourism & $\checkmark$ & Enjoying the scenery \\
$\checkmark$ & Cultural tourism & $\checkmark$ & Enjoying the trading activity of the local people along the river \\
$\checkmark$ & Culinary tourism & $\checkmark$ & fishing and enjoying the traditional food \\
$\checkmark$ & Edutourism & $\checkmark$ & Seeing and enjoying the local settlement (house on stilts) alongside the river \\
$\checkmark$ & Ecotourism & $\checkmark$ & Enjoying the traditional life of the local people \\
& $\checkmark$ & Enjoying the local people activity alongside the river \\
& $\checkmark$ & Enjoying to row down the river by using traditional boat (jukung) \\
& $\checkmark$ & Learning about history \\
& $\checkmark$ & Enjoying the scenery and the crop from the local plantation by picking the crop from \\
& $\checkmark$ & the trees \\
&
\end{tabular}




\section{COMMUNITY-BASED TOURISM}

The participation of local people in tourism development recently received a lot of attention among scholars. There are numerous benefits of community based tourism. Community based tourism enhance the local economy development. The community based tourism open new windows for the development of remotes area. Many countries has been implemented community based tourism as a strategy for tourism development which able to increase and enhance local economic development [13].

As far, the evidence of community based tourism in Lok Baitan floating market was absent. Visitor come to floating market usually are in short time, following the operational times of floating market. This occurs due to the absence of tourism programs. The environment of tourism and hospitality among Banjarese along Barito Rivers was absent due to the long absent of tourism program, especially community development program in tourism.

Several aspect can be supported to meet sustainable and community based tourism in Lok Baitan Villages. For instance, the villagers' houses can also provide as a home stay for the tourists who want to stay and feel and interact directly with the local people. Problems related to the integration of settlement into tourism facility related to the quality of house, especially its health environment and sanitation. As far the health quality was poor and need to be improved. The local government should be able to changes the local people perspective to manage environment and promotes tourism as ne economic prospect. Therefore, it is the challenges and opportunities for stakeholder and local government to establish community based tourism program in Lok Baitan. In many area where sustainable tourism implemented, the involvement of local government and stakeholder was crucial [13].

\section{CONCLUSION}

It is clear that floating market in South Kalimantan is one of the potential tourism attractions. There are two important resources for tourism attraction, namely natural and cultural resources. The management of both resources was important and should be draft integratively and supported by regulation which area issued by provincial and regency levels. The development of floating market in Lok Baitan, therefore, should be implemented following sustainable development principles. From the richness of natural and cultural resources, there are opportunities for the development of numerous tourism program. In such a case, involving local community was important. The community based tourism is one of the strategy tourism development in Lok Baitan.

\section{REFERENCES}

[1] Sharma, K. K. 2004. Tourism and regional development. Sarup and Sons. New Delhi.

[2] Koens, J.F., C. Dieperink, and M. Miranda. 2009. Ecotourism as a development strategy: experiences from Costa Rica. Journal of Environment, Development and Sustainability 11(6), 1225-1237.

[3] Fuller, D. O., T. C. Jessup, and A. Salim. 2004. Loss of forest cover in Kalimantan, Indonesia, since the 1997-1998 El Nino. Conservation Biology 18(1), 249-254.

[4] Rahu, A. A., K. Hidayat, M. Ariyadi, and L. Hakim. 2014. Management of Kaleka (traditional gardens) in Dayak community in Kapuas, Central Kalimantan. International Journal of Science and Research 3(3), 205210.

[5] Hakim, L., J. E. Kim, and S. K. Hong. 2009. Cultural landscape and ecotourism in Bali Island, Indonesia. Journal of Ecology and Environment 32(1), 1-8.

[6] Rahmini, N., M. Pudjihardjo, A. Hoetoro, and A. Manzilati. 2015. The role of bonding, bridging and linking at traditional markets in Indonesia: a study at Lok Baintan floating market Banjar Regency South Kalimantan. Journal of Apllied Economic and Bussiness 3(3), 76-88.

[7] MacKinnon, K. 1996. The ecology of Kalimantan Vol. 3. Oxford University Press.

[8] Dudgeon, D. 2000. The ecology of tropical Asian rivers and streams in relation to biodiversity conservation. Annual Review of Ecology and Systematics, 239-263.

[9] Margules, C., S. Sarkar, and C. R. Margules. 2007. Systematic conservation planning. Cambridge University Press.

[10] Kirshenblatt-Gimblett, B. 1998. Destination culture: Tourism, museums, and heritage. University of California Press.

[11] Long, L. M. 1998. Culinary tourism 55(3). University Press of Kentucky.

[12] Inskeep, E. 1991. Tourism planning: an integrated and sustainable development approach. Van Nostrand Reinhold.

[13] Russell, P. 2000. Community-based tourism. Travel and Tourism Analyst 5, 89-116. 